\title{
AN ANALYSIS OF COHESION IN SHORT STORY “THE GIFT OF MAGI"
}

\author{
By:
}

\author{
Zainuddin,S.S.,M.Hum ${ }^{1}$
}

\begin{abstract}
The researcher focuses the study on an analysis of Cohesion in short Story "The Gift of Magi". The research is done through descriptive qualitative, in which the aims of the research are to describe the cohesion in short story, and then to determine the cohesion used dominantly in short story. Consequently, the researcher needs short story "The Gift of Magi" for primary data, and then some related Journals and books about Cohesion. Furthermore, the researcher uses content analysis method for analyzing the data. There the technique of analyzing the data; Reading the story, Analyzing cohesion in the story, and taking conclusion of overall discussion.
\end{abstract}

\section{A. INTRODUCTION}

As a homo socius, people need communication to interact with another. Communication among people is devided into two kinds. They are direct communication and indirect communication. Direct communication means talking to other by face to face or speaking in spoken form. While indirect communication means could be done by the fast reaction process or writing in written form.

The written discourse is meant planned to be permanent, and it reflects to transactional purpose; and transfers the information. On the other hand, the spoken discourse is intended to be transitory and it has an interactional function; to establish relationship with people. Therefore, the differencies between spoken and written language are how types of communication are perfomed formally. ${ }^{2}$

Short story is the source of this research. Short story is the best for English learning. from short story, the reader can get more time to focus on individual words. When a text is short, the reader can devote more time to learn how every single word is used and what importance ot has in piece.

Then, from short story, the reader can focus more on ides and concept. Language is less about words and more about the meaning behind them.

\footnotetext{
${ }^{1}$ Writer is an English Department Lecturer of Tarbiyah and Teacher Training Faculty (FTIK), Institute for Islamic Studies (IAIN) Padangsidimpuan.

${ }^{2}$ Donald Ary, et.al, Introduction to Research in Education (USA: Wadsworth, 2010), p. 457
} 
Additionally, Cohesion refers to relation of meaning which exists within the text. cohesion occurs when the interpretation of some elements in discourse dependet on that of another. That one presupposes the other, in the sense that it can not be effectively decoded except by recourse. Then this thing happens, a relation of cohesion is set up, and the two elements, the presupposing and the presupposed are thereby at least potentially integrated into a text.

In conclusion, the researcher would conduct the research aboutAn analysis of Cohesion in Short Story "The Gift of Magi”.

\section{B. DISCUSSION}

Cohesion refers to relation of meaning which exists within the text. cohesion occurs when the interpretation of some elements in discourse dependent on that of another. In short story entitled "The Gift of Magi”, there are some kinds of cohesion that has been found. All kinds of cohesion devices found there ${ }^{3}$.

First, reference. There are 44 references that found in the story. Almost all of the conjunction represented by conjunction "and". The second kind is substitution. For substitution, it is not too much. Substitution only occurred in the story twice. Next, ellipsis also only 3 in the story. The last is conjunction. For conjunction, there are 39 conjunctions that found in the novel.

Based on the findings, the most dominant type of cohesion that occurred is reference, 44 in total with percentage $50.57 \%$.

\section{FINDINGS}

\section{The used of Cohesion Devices in Short Story}

The data was analyzed based on the aim to identify the cohesion devices uses. From the short story entitled "The Gifh of Magi" there are some cohesion devices that found in the story. The uses of cohesion devices in the short story described as follows:

${ }^{3}$ DewiMustikaArifani, An Analysis of Grammatical and Lexical Cohesion in Emma Watspn's Speech Text on Gender Equality, A Thesis, Jakarta, 2016, p. 16 


\section{a. Reference}

Table 1. The Reference in Short Story "The Gift of Magi”

\begin{tabular}{|c|c|c|}
\hline \multirow{4}{*}{$\begin{array}{l}\operatorname{Prg} \\
1\end{array}$} & Clause & Types of Cohesion \\
\hline & $\begin{array}{l}\text { One dollar and eighty- } \\
\text { seven cents. That was all. } \\
\text { And sixty cents of it was } \\
\text { in pennies }\end{array}$ & $\begin{array}{l}\text { Satu dolar dan delapan puluh tujuh sen.Itu } \\
\text { semuanya. }\end{array}$ \\
\hline & $\begin{array}{l}\text { Three times Della } \\
\text { counted it }\end{array}$ & $\begin{array}{l}\text { Dan enam puluh sen dari delapan puluh tujuh } \\
\text { dolar adalah uang receh }\end{array}$ \\
\hline & & Tiga kali Della menghitung uang itu \\
\hline 2 & $\begin{array}{l}\text { So Della did it } \\
\text { It did not exactly beggar } \\
\text { description }\end{array}$ & $\begin{array}{l}\text { Della melakukan itu } \\
\text { Itu bukanlah deskripsi yang pas tentang } \\
\text { seorang pengemis }\end{array}$ \\
\hline 3 & $\begin{array}{l}\text { But whenever Mr.James } \\
\text { Dillingham Young came } \\
\text { home and reached his } \\
\text { flat above he was called } \\
\text { 'Jim' and greatly hugged } \\
\text { by Mrs. James }\end{array}$ & $\begin{array}{l}\text { Tapi, kapanpun Mr.James pulang kerumah } \\
\text { dan mencapai flatnya di atas, dia dipanggil } \\
\text { "Jim" dan dipeluk oleh James }\end{array}$ \\
\hline 4 & $\begin{array}{l}\text { she stood by the window } \\
\text { and looked out dully at a } \\
\text { grey cat walking a grey } \\
\text { fence in a grey backyard. } \\
\text { She had been saving } \\
\text { every penny she could } \\
\text { formonths, }\end{array}$ & $\begin{array}{l}\text { Dia berdiri di dekat jendela dan melihat } \\
\text { kucingabu-abu itu berjalan tanpa jalan di } \\
\text { halaman belakang yang kelabu }\end{array}$ \\
\hline 5 & $\begin{array}{l}\text { Expenses had been } \\
\text { greater than she had } \\
\text { calculated } \\
\text { Suddenly she whirled } \\
\text { from the window and } \\
\text { stood before the glass }\end{array}$ & $\begin{array}{l}\text { Biaya sudah lebih besar daripada yang telah ia } \\
\text { hitung }\end{array}$ \\
\hline 6 & $\begin{array}{l}\text { Jim would have pulled } \\
\text { out his watch every time } \\
\text { he passed. }\end{array}$ & $\begin{array}{l}\text { Jim telah mengeluaraka narloinya setiap kali } \\
\text { ia melewatinya }\end{array}$ \\
\hline
\end{tabular}




\begin{tabular}{|c|c|c|}
\hline 7 & $\begin{array}{l}\text { It reached below her } \\
\text { knee and made itself } \\
\text { almost a garment for her } \\
\text { And then she did it up } \\
\text { again nervously and } \\
\text { quickly } \\
\text { Once she faltered for a } \\
\text { minute and stood } \\
\text { She fluttered out of the } \\
\text { door and down the stairs } \\
\text { to the street }\end{array}$ & $\begin{array}{l}\text { elama dia tersendat selama satu menit dan } \\
\text { erdiri } \\
\text { ia terbang keluar dari pintu dan menuruni } \\
\text { angga kejalan }\end{array}$ \\
\hline 8 & $\begin{array}{l}\text { here she stopped the } \\
\text { gn read }\end{array}$ & jiman \\
\hline 9 & $\begin{array}{l}\text { 'Give it to me quick } \\
\text { She was ransacking the } \\
\text { stores for Jim's present } \\
\text { She found it at last. } \\
\text { It surely had been made } \\
\text { for Jim and no one else. } \\
\text { it must be Jim's } \\
\text { and she hurried home } \\
\text { with the } 87 \text { cents. } \\
\text { he sometimes looked }\end{array}$ & $\begin{array}{l}\text { Itu benar-benar dibuat untuk Jim dan bukan } \\
\text { orang lain } \\
\text { Itu harus menjadi milik Jim Dan dia bergegas } \\
\text { pulang dengan } 87 \text { sen } \\
\text { Dia terkadang terlihat }\end{array}$ \\
\hline 10 & $\begin{array}{l}\text { She got out her curling } \\
\text { irons and lighted the gas } \\
\text { and went to work } \\
\text { She looked at her } \\
\text { reflection in the mirror } \\
\text { long } \\
\text { she said to herself }\end{array}$ & $\begin{array}{l}\text { dia mengeluarkan curling ironnya dan } \\
\text { menyalakan gas dan pergi bekerja } \\
\text { dia melihat bayangannya di cermin yang } \\
\text { panjang } \\
\text { dia berkata pada dirinya sendiri }\end{array}$ \\
\hline 11 & $\begin{array}{l}\text { Then she heard his step } \\
\text { on the stair away } \\
\text { and she turned white for } \\
\text { just a moment } \\
\text { she had a habit of saying } \\
\text { little silent prayers } \\
\text { 'Please God, make him }\end{array}$ & $\begin{array}{l}\text { Kemudian dia mendengar langkahnya di } \\
\text { tangga } \\
\text { Dia berubah pucat beberapa saat } \\
\text { Dia memiliki kebiasaan mengucapkan doa } \\
\text { diam-diam } \\
\text { Ku mohonTuhan, buat ia berpikir aku masih }\end{array}$ \\
\hline
\end{tabular}




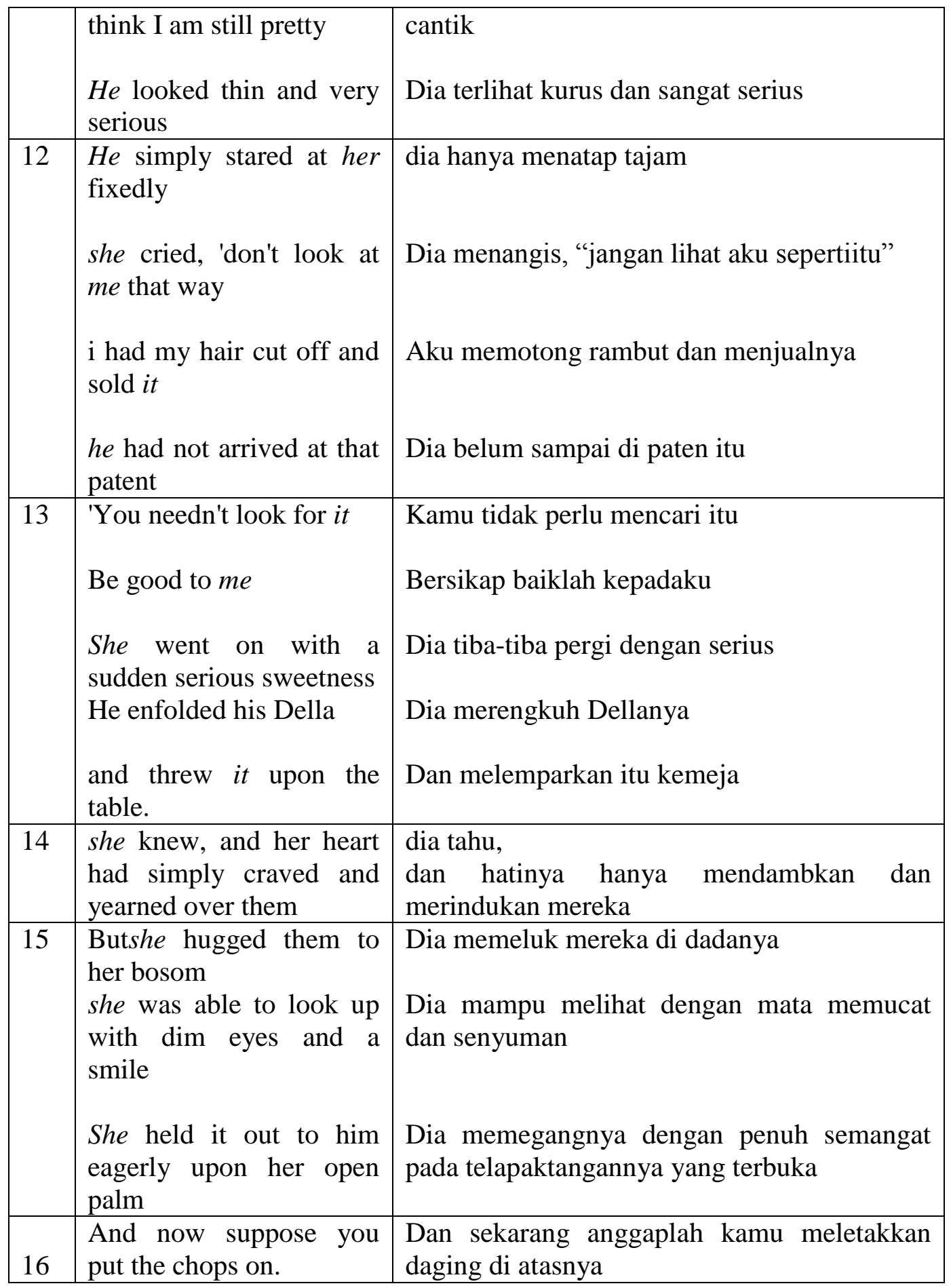

*Note:Reference is the relation between as element of the text which is interpreted by the participants. After analyzing the data, the researcher found some clauses that consists of reference, such as:

1) One dollar and eighty-seven cents. That was all.

The sentence above consist of reference which signed by italic. "That" belongs to reference. The use of demonstrative "that" refers "One dollar and eighty-seven cents". 
2) And sixty cents of it was in pennies

The sentence above consist of reference which signed by italic. "It" belongs to reference. The use of pronoun "it" refers "One dollar and eighty-seven cents".

3) But whenever Mr.James Dillingham Young came home and reached his flat above he was called 'Jim'

The sentence above consist of reference which signed by italic. "He" belongs to reference. The use of pronoun "He" refers "Mr.James Dillingham Young".

4) She stood by the window and looked out dully at a grey cat walking a grey fence in a grey backyard

The sentence above consist of reference which signed by italic. "She" belongs to reference. The use of pronoun "She" refers to "Della"in previous sentence or context.

5) Jim would have pulled out his watch every time he passed.

The sentence above consist of reference which signed by italic. "He" belongs to reference. The use of pronoun "He" refers to "Jim".

\section{1) Substituion}

Table 2.Substituion in Short Story

\begin{tabular}{|l|l|l|}
\hline Paragraph & Clause & Meaning \\
\hline 6 & $\begin{array}{l}\text { One was Jim's gold } \\
\text { watch that had been his } \\
\text { father's and his } \\
\text { grandfather's } \\
\text { The other one was } \\
\text { Della's hair }\end{array}$ & $\begin{array}{l}\text { Salah satunyaadalah jam } \\
\text { tanganemas yang } \\
\text { merupakanmilikayahnyadankake } \\
\text { knya } \\
\text { Satunyalagiadalahrambutdela }\end{array}$ \\
\hline
\end{tabular}

*Note: Substituion is the replacement of one item by another. Substitution holds a text together through preventing repetition and creating cohesive grammatical cohesion, not in meaning, but in the wording, between words, clauses and phrases.

After analyzing the data, the researcher found some clauses or sentences that consist of substituion, such as:

1) One was Jim's gold watch that had been his father's and his grandfather's

The sentence above consists of substituion which signed by italic.

"One" belongs to substituion. The "one" used to substitute the clause "there were two possessions of the James Dillingham" in previous sentence.

2) The other one was Della's hair 


\begin{tabular}{|c|c|c|}
\hline Parg & Clause & Meaning \\
\hline 1 & $\begin{array}{l}\text { One dollar and eighty-seven cents } \\
\text { And sixty cents of it was in pennies } \\
\text { Pennies saved one and two at a } \\
\text { time by bulldosing the grocer and } \\
\text { the vegetable man and the butcher } \\
\text { until one's cheeck with the silent } \\
\text { imputation of parsimony that such } \\
\text { close dealing implied } \\
\text { And the next day would be } \\
\text { Christmas. }\end{array}$ & $\begin{array}{l}\text { Satu dolar dan delapan puluh tujuh sen.Itu } \\
\text { semuanya. } \\
\text { Dan enam puluh sen dari delapan puluh } \\
\text { tujuh dolar adalah uang receh. Uang receh } \\
\text { disimpan dalam satu dan dua sekaligus } \\
\text { membuldozer took kelontong dan tukang } \\
\text { jual sayur dan daging untuk pipi seseorang } \\
\text { dengan imparasi diam dari parsomoni } \\
\text { yang disepakati seperti itu } \\
\text { Dan hari selanjutnya Natal }\end{array}$ \\
\hline 2 & $\begin{array}{l}\text { There was clearly nothing to do but } \\
\text { flop down on the shabby little } \\
\text { couch and howl } \\
\text { Which instigates the moral } \\
\text { reflection that life is made up of } \\
\text { sobs, sniffles, and smiles. } \\
\text { But it certainly had that word on the } \\
\text { look out for the mendicancy squad } \\
\text { In the vestibule belows was a letter- } \\
\text { box into which no letter would go, } \\
\text { and an electric finger could coax a } \\
\text { ring. }\end{array}$ & $\begin{array}{l}\text { Jelas tidak ada yang bias dilakukan kecuali } \\
\text { menjatuhkan diri ke sofa dan lolongan } \\
\text { lusuh } \\
\text { Yang menghasut refleksi moral bahwa } \\
\text { hidup terdiri dari isak tangis dan senyum } \\
\text { Tapi tentu saa itu bekerja pada tampilan } \\
\text { luar untuk sekolompok pengemis } \\
\text { Di ruang deoan di bawah ada surat yang } \\
\text { tidak ada surat tidak bias masuk dan listik } \\
\text { yang membujuk sebuah jari }\end{array}$ \\
\hline 3 & $\begin{array}{l}\text { As though they were thingking } \\
\text { seriously of contracting to a modest } \\
\text { and unassuming } \mathrm{D} \text {. }\end{array}$ & $\begin{array}{l}\text { Seolah-olah mereka berpikir serius untuk } \\
\text { membuat kontrak menjadi sederhana dan } \\
\text { tidak menarik }\end{array}$ \\
\hline 4 & $\begin{array}{l}\text { Tomorrow would be Christmast } \\
\text { Day, and she had only } \$ 1.87 \text { with } \\
\text { which to buy Jim a present. }\end{array}$ & $\begin{array}{l}\text { Besok adalah hari Natal, dan dia hanya } \\
\text { punya } 1.87 \text { dollar untuk membelikan Jim } \\
\text { hadiah }\end{array}$ \\
\hline 5 & $\begin{array}{l}\text { Something fine and rare and } \\
\text { sterling } \\
\text { a very thin and very agile person } \\
\text { may } \\
\text { she whirled from the window and } \\
\text { stood before the glass }\end{array}$ & $\begin{array}{l}\text { sesuatu yang bagus, langka dan sterling } \\
\text { seorang yang sangat kurus dan mungkin } \\
\text { sangat lincah } \\
\text { Dia berputar dari jendela dan berdiri di } \\
\text { depan kaca }\end{array}$ \\
\hline
\end{tabular}




\begin{tabular}{|c|c|c|}
\hline 7 & $\begin{array}{l}\text { And then she did it } \\
\text { she faltered for a minute and stood } \\
\text { With a whirl of skirts and with the } \\
\text { brilliant sparkle } \\
\text { and down the stairs to the street }\end{array}$ & $\begin{array}{l}\text { dan kemudian dia melakukan itu } \\
\text { dia tersendat selalama beberapa saat dan } \\
\text { berdiri dengan putaran rok dan sparkel } \\
\text { yang berlian dan menuruni tangga kejalan }\end{array}$ \\
\hline 8 & $\begin{array}{l}\text { One flight up Della ran, collected } \\
\text { herself and painting. }\end{array}$ & $\begin{array}{l}\text { Satu penerbangan Bella naik, } \\
\text { mengumpulkan diri dan melukis }\end{array}$ \\
\hline 9 & $\begin{array}{l}\text { and the next two hours tripped by } \\
\text { on rosy wings } \\
\text { andno one else. } \\
\text { Andshe had turned all of them } \\
\text { inside out } \\
\text { quiteness and value } \\
\text { and she hurried home with the } 87 \\
\text { cents }\end{array}$ & $\begin{array}{l}\text { dan dua jam perjalanan berikutnya dengan } \\
\text { sayap rosy } \\
\text { dan tak ada orang lain } \\
\text { dan dia berubah pucat } \\
\text { ketenangan dan nilai } \\
\text { dia bergegas pulang dengan } 87 \text { sen }\end{array}$ \\
\hline 10 & $\begin{array}{l}\text { and lighted the gas and went to } \\
\text { work } \\
\text { Carefully and critically } \\
\text { But what could I do } \\
\text { Could I do with a dollar and eighty- } \\
\text { seven cents? }\end{array}$ & $\begin{array}{l}\text { Dan menyalakan lampu dan gas dan pergi } \\
\text { bekerja } \\
\text { Dengan hati hati dan kritis } \\
\text { Tapi apa yang bias aku lakukan } \\
\text { Bisakah aku lakukan satu dollar dalam } 87 \\
\text { sen? }\end{array}$ \\
\hline 11 & $\begin{array}{l}\text { Della doubled the fob chain in her } \\
\text { hand and sat on the corner of the } \\
\text { table } \\
\text { and she turned white for just a } \\
\text { moment. } \\
\text { The door opened and Jim stepped } \\
\text { in and closed it } \\
\text { He looked thin and very serious }\end{array}$ & $\begin{array}{l}\text { Della menggandakan rantai fob di } \\
\text { tangannya dan dudui di sudut meja } \\
\text { Dia berubah pucat selama beberapa waktu } \\
\text { Pintu dibuka dan Jim melangkah dan } \\
\text { menutup pintu } \\
\text { Dia terlihat kurus dan sangat serius }\end{array}$ \\
\hline 13 & and threw it upon the table. & Dan melemparkannya kemeja \\
\hline 14 & $\begin{array}{l}\text { White fingers and nimble tore at } \\
\text { the string and paper. } \\
\text { And then an ecstatic scream of joy } \\
\text { she knew, and her heart had simply } \\
\text { craved and yearned over them }\end{array}$ & $\begin{array}{l}\text { Jari-jari putih dan torehan gesit pada tali } \\
\text { dan kertas } \\
\text { Dan kemudian teriakan kegembiraan yang } \\
\text { luar biasa } \\
\text { Dia tahu, dan hatinya mendambakan dan } \\
\text { merindukan mereka }\end{array}$ \\
\hline 15 & $\begin{array}{l}\text { Butshe hugged them to her bosom } \\
\text { she was able to look up with dim } \\
\text { eyes and a smile }\end{array}$ & $\begin{array}{l}\text { Tapi dia memeluk mereka kedadanya } \\
\text { Dia mampu melihat dengan mata memucat } \\
\text { dan senyuman }\end{array}$ \\
\hline 16 & $\begin{array}{l}\text { And now suppose you put the chops } \\
\text { on. }\end{array}$ & $\begin{array}{l}\text { Dan sekarang anggaplah kamu meletakkan } \\
\text { daging di atasnya }\end{array}$ \\
\hline
\end{tabular}


The sentence above consist of substituion which signed by italic. "the other one" belongs to substituion. The "one" used to substitute the clause "there were two possessions of the James Dillingham" in previous sentence.

\section{c. Ellipsis}

Table 3. Ellipsis in Short Story

\begin{tabular}{|l|l|l|}
\hline Paragraph & Clause & Meaning \\
\hline 3 & $\begin{array}{l}\text { already introduced to } \\
\text { you as Della }\end{array}$ & $\begin{array}{l}\text { Sudahdiperkenalkankepadamu } \\
\text { Della }\end{array}$ \\
\hline 5 & $\begin{array}{l}\text { Della, being slender, had } \\
\text { mastered the art. }\end{array}$ & $\begin{array}{l}\text { Della, yang ramping, } \\
\text { diatelahmenguasaiseni }\end{array}$ \\
\hline
\end{tabular}

*Note: When the linguistic unit of the sentence is omitted and replaced by nothing, it is called "ellipsis". After analyzing the data, the researcher found some clauses or sentences that consist of ellipsis, such as:

1) Della, being slender, had mastered the art.

The sentence above consist of ellipsis. In the pattern, in order to arrange a sentence, it should be formed by subject and predicate minimally. But, in the sentence "had mastered the art", there is no use of subject. But, the reader can comprehend that the subject of the sentence is "Della". Della in the sentence is omitted and replaced by nothing, but it still can be understood.

2) Already introduced to you as Della

The sentence above consist of ellipsis. In the pattern, in order to arrange a sentence, it should be formed by subject and predicate minimally. But, in the sentence "already introduced to you as Della

", there is no use of subject. But, the reader can comprehend that the subject of the sentence is "Jim".Jim in the sentence is omitted and replaced by nothing, but it still can be understood.

\section{d. Conjunction}

*Note: Conjunction is the relationship which indicates how the subsequent sentence or clause should be linked to the preceding or the following (part 
of the) sentence. After analyzing the data, the researcher found some clauses or sentences that consist of conjunction, such as:

1) One dollar and eighty-seven cents

The sentence above consist of conjunction which is pointed by italic "and". The conjunction "and" used to connect between the previous and the next clause which is equal.

2) And then she did it up again nervously and quickly

The sentence above consist of conjunction which is pointed by italic "and". The conjunction "and" used to connect between the previous and the next clause which is equal.

3) She fluttered out of the door and down the stairs to the street

The sentence above consist of conjunction which is pointed by italic "and". The conjunction "and" used to connect between the previous and the next clause which is equal.

4) With a whirl of skirts and with the brilliant sparkle

The sentence above consist of conjunction which is pointed by italic "and". The conjunction "and" used to connect between the previous and the next clause which is equal.

5) She fluttered out of the door and down the stairs to the street

The sentence above consist of conjunction which is pointed by italic "and". The conjunction "and" used to connect between the previous and the next clause which is equal.

\section{The Dominant Cohesion used in Short Story "The Gift of Magi"}

After the researcher analyze the data and found some cohesion devices in the story, the researcher concluded the used of cohesion devices as follows:

Table 2. The Use of Cohesion Devices

\begin{tabular}{|l|l|l|l|}
\hline & Types of Cohesion & Total & Percentage \\
\hline & Reference & 44 & $50.57 \%$ \\
\hline & Substitution & 39 & $44.83 \%$ \\
\hline & Ellipsis & 2 & $2.30 \%$ \\
\hline & Conjunction & 2 & $2.30 \%$ \\
\hline & Total & 87 & $100 \%$ \\
\hline
\end{tabular}


Based on the table, it can be concluded that the most dominant type of cohesion which is used in short story "The Gift of magi" is reference in total 44 times per 87 occurred in the story with percentage $50.57 \%$.

\section{CONCLUSION}

Based on the findings, the conclusions of this research are:

1. Cohesion refers to relation of meaning which exists within the text. Cohesion occurs when the interpretation of some elements in discourse dependent on that of another. In short story entitled "The Gift of Magi", there are some kinds of cohesion that has been found. All kinds of cohesion devices found there. There are 44 for reference with percentage $50.57 \%$. there are 2 for substitution with percentage $2.30 \%$. There are 2 for ellipsis with percentage $2.30 \%$. and there are 30.39 for conjunction with percentage $44.83 \%$.

2. Based on the finding, the dominant type of cohesion that used in story The Gift of Magi is "reference" 44 in total with percentage $44.83 \%$. almost half of the story consist of reference. 


\section{ENGIISH EDUCATION \\ VOL. 06 NO. 1. JUNY 2018}

\section{REFERENCES}

Ary, Donald et.al, Introduction to Research in Education, USA: Wadsworth, 2010

Amirul Hadi\& Haryono, Metodologi Penelitian, (Bandung: Pustaka Setia, 1998).

Dewi Mustika Arifani, An Analysis of Grammatical and Lexical Cohesion in Emma

Watspn's Speech Text on Gender Equality, A Thesis, Jakarta, 2016

Gay L.R. and Peter Airasian, Education Research: Competence for Analysis and Application, USA: Prectice Hall, 2000

Halliday, M.A.K. Introduction to Functional Grammar, New York: Routledge, 2014

Harmer, Jeremy, The Practice of English Language Teaching, (London: Longman, 2001)

Hornby, A.S, A P Cowie, et. al., Oxford Advanced Learner's Dictionary of Current English(New York : Oxford University Press, 1974).

Mason, Jenifer Qualitative Research, London: SAGE Publications, 2002

Noeng Muhadja, Metodologi Peneltian Kualitatif, Yogyakarta: Rake Sarasan, 1992

Suharsimi Arikunto, Prosedur Penelitian Suatu PendekatanPraktik, Jakarta: Rineka Cipta, 2006 